Review

\title{
Electrochemical Sensors for Antibiotic Susceptibility Testing: Strategies and Applications
}

\author{
Dongmin Kim ${ }^{1}$ and Seungmin Yoo ${ }^{2, *} \mathbb{C}$ \\ 1 Center for Applied Life Science, Hanbat National University, Daejeon 34158, Korea; dmk.iqbio@gmail.com \\ 2 School of Integrative Engineering, Chung-Ang University, Seoul 06974, Korea \\ * Correspondence: yooseun1@cau.ac.kr
}

check for updates

Citation: Kim, D.; Yoo, S. Electrochemical Sensors for Antibiotic Susceptibility Testing: Strategies and Applications.

Chemosensors 2022, 10, 53.

https://doi.org/10.3390/ chemosensors 10020053

Academic Editor: Núria Serrano

Received: 28 December 2021

Accepted: 26 January 2022

Published: 29 January 2022

Publisher's Note: MDPI stays neutral with regard to jurisdictional claims in published maps and institutional affiliations.

Copyright: (C) 2022 by the authors. Licensee MDPI, Basel, Switzerland. This article is an open access article distributed under the terms and conditions of the Creative Commons Attribution (CC BY) license (https:// creativecommons.org/licenses/by/ $4.0 /)$.

\begin{abstract}
Increasing awareness of the impacts of infectious diseases has driven the development of advanced techniques for detecting pathogens in clinical and environmental settings. However, this process is hindered by the complexity and variability inherent in antibiotic-resistant species. A great deal of effort has been put into the development of antibiotic-resistance/susceptibility testing (AST) sensors and systems to administer proper drugs for patient-tailored therapy. Electrochemical sensors have garnered increasing attention due to their powerful potential to allow rapid, sensitive, and real-time monitoring, alongside the low-cost production, feasibility of minimization, and easy integration with other techniques. This review focuses on the recent advances in electrochemical sensing strategies that have been used to determine the level of antibiotic resistance/susceptibility of pathogenic bacteria. The recent examples of the current electrochemical AST sensors discussed here are classified into four categories according to what is detected and quantitated: the presence of antibiotic-resistant genes, changes in impedance caused by cell lysis, current response caused by changes in cellular membrane properties, and changes in the redox state of redox molecules. It also discusses potential strategies for the development of electrochemical AST sensors, with the goal of broadening their practical applications across various scientific and technological fields.
\end{abstract}

Keywords: antibiotic resistance; bacteria; antibiotic susceptibility testing; electrochemical detection; electrochemical sensor; electrode

\section{Introduction}

The increase in the danger from and speed of the emergency of antibiotic-resistant pathogens has become a public health issue of global concern. In particular, the rapid global spread of multi- and pan-resistant bacteria is alarming because of the difficulty of treatment or no cure with existing antibiotics.

Antibiotic resistance occurs when microorganisms, such as bacteria and fungi, develop the ability to resist the substances that kill them. Subsequently, the antibiotic-resistant microorganisms are not killed and continue to grow. In microbial infection in clinical settings, antibiotic resistance increases medical costs, prolongs hospital stays, and increases mortality. Approximately 2.8 million illnesses and 35,000 deaths occur in the USA annually [1], and $>33,000$ people are killed each year due to antibiotic-resistant infections [2]. According to a report by the $\mathrm{WHO}$, antibiotic resistance is one of the top 10 global public health threats and may cause approximately 10 million deaths by 2050 [3-5]. In this regard, the infecting agent should be identified and antibiotic-susceptibility testing (AST) should be performed to determine the optimum treatment regimen.

The resistance level of a pathogenic species to specific drugs is evaluated through AST measurements. The current gold standards for AST rely on culture-based methods such as broth dilution, agar dilution, disk diffusion, and gradient diffusion stripe tests, which are generally based on monitoring the growth of bacteria that have either formed inhibition haloes in agar plates or turbidity in liquid media [6]. Despite being well-established and 
widely adopted, the existing growth-based methods require several conditions for practical use [7-10]. Pure isolates should be used when performing culture enrichment, which takes several days. After inoculating the isolates on agar or broth media, the results are obtained in approximately 1-2 days. However, these methods require large sample volumes and have poor quantification capabilities. Due to these limitations, the problem of antibiotic resistance will likely continue and increase healthcare costs.

To overcome these limitations, tremendous efforts have been put into developing sensors that use diverse sensing approaches, such as optical, electrical, electrochemical, and mechanical methods [4,7,10-15]. Of these, electrochemical sensors including amperometric sensors, potentiometric sensors, and impedance sensors, have been actively applied to detect a wide range of molecules [16-18]. Electrochemical sensing approach possesses the advantages of simple sensor design, quick response, high sensitivity, simplicity of use, miniaturization, reduced costs of testing and production, development of disposal devices, and real-time data readout, instrument-free system, enabling point-of-care testing even at regions with limited resources to perform healthcare diagnostics and environmental monitoring without the need of the skilled workers [19-28]. Further small amounts of sample are required for analyte in the presence of other molecules, even in turbid real samples. Another advantage is the ease of integration with other types of sensors, such as optical sensors, or technologies, including microfluidics, whereby multiplex detection can be achieved with enhanced accuracy and precision. Furthermore, remarkable advances in novel materials, sensing platform, and emerging technology make the electrochemical sensor very valuable and powerful in analytical tool. Nanomaterials and nanostructuresenabled electrochemical sensors exhibited reduced over-potential, fast electron transfer kinetics, and diffusion/mass transfer of analyte compared to conventional electrochemical sensors, facilitating the development of sensitive and specific biosensors, as well as novel sensing strategies [23,29-34]. For instance, electrodes with nanoscale cavities provided an environment that promotes electrochemical sensing reactions and the amplification of electrochemical signal, eventually yielding high sensitivity [29,34]. Functional nanomaterials provided high catalytic activity, electric conductivity, and biocompatibility to accelerate the signal transduction and amplified biorecognition events with signal tags. The use of such functional nanomaterials has also enabled the diverse and effective immobilization for the functionalization of electrode surface, leading to highly sensitive and specific biosensing. The application of nano-impact electrochemistry which is based on the faradaic charge transfer, following the collision of redox active entities on the nano or microscale with an electrode, has also provided an enhanced sensitivity for the detection of molecule at a single-entity level [35-40]. Recent contributions in 3D-printing technology have resulted in the development of fine-tuned and tailor-made printed electrode devices and systems by embedding and/or immobilizing nanostructured materials, which offer enhanced sensing performance, cost-effectiveness, and scalability [41,42]. Diversity of electrochemical sensing methods including electrochemical impedance spectroscopy (EIS), cyclic voltammetry (CV), differential pulse voltammetry (DPV), and square wave voltammetry (SWV), can also be advantageous in analyzing and detecting diverse molecules depending on the desired purpose. For example, EIS which measures the electrical resistance (impedance) of the metal/solution interface over a wide frequency range, provides the information on the kinetics multiple electrochemical processes. CV is one of the most ubiquitous electrochemical methods, in which the potential is linearly applied to the working electrode and the current is measured as a function of time. This method has become well-established as a fast and reliable characterization tool and provides diverse information on electron transfer reactions. DPV is one of voltametric method that is usually used to measure the concentration of specific electroactive species. DPV is very sensitive and enables a label-free detection. SWV which is another type of a voltametric method, involves stepping a series of forward and reverse pulses at the working electrode from initial potential to final potential and the current difference is analyzed between forward and reverse pulses. The current is 
measured at each pulse, which can minimize the measurement of background current with high sensitivity.

Several reviews provide detailed information on the principles and characteristics of electrochemical sensors $[19,22,25,43-46]$. In this review, we aim to present recent advances and developments in the field of electrochemical sensors that assess and monitor the antibiotic resistance of pathogenic bacteria in vitro. This review categorizes electrochemical AST sensors into four groups according to the following sensing strategies: (1) detection of antibiotic-resistant genes, (2) assessment of the resistance change caused by cell lysis, (3) assessment of the current response caused by changes in membrane properties, and (4) assessment of the redox changes in a redox-active molecule affected by bacterial metabolic activity. Representative applications of electrochemical sensors using these strategies are also described in the following sections.

\section{Electrochemical Sensors for Determining the Antibiotic Resistance Level of Bacteria} Electrochemical Sensing Strategy for Determining Antibiotic Resistance/Susceptibility

A bacterial genotypic or phenotypic change is a factor in determining antibiotic resistance/susceptibility. Genotypic susceptibility testing relies on examining the presence or absence of antibiotic-resistant gene(s) or mutants with modified nucleotides because antibiotic-resistant bacteria have the related genes and/or mutations at the genome level. This genotypic testing is a straight-forward method for AST but it often limits quantification of the level of antibiotic resistance/susceptibility. Phenotypic susceptibility testing focuses on monitoring cell viability, membrane structural change, and metabolic activity caused by the interaction of bacterial cells and antibiotics. Phenotypic testing is advantageous for measuring the level of resistance. Electrochemical AST sensors were developed based on several systems that harness these genotypic and phenotypic changes of bacteria. The first system is based on the detection of antibiotic-resistant genes [47-50]. A DNA fragment can be immobilized on an electrode to act as a bait (capture DNA) that binds to antibioticresistant genes or mutants. Intracellular genomic DNAs are extracted and applied to the electrode with the capture DNA. If the genomic DNA is scarce, it can be amplified via PCR before applying to the electrode. For the detection of duplex DNA formed by hybridization of target and capture DNA, labeling with dye and addition of reagent can be used, and duplex DNA is detected by measuring the change in capacitance, impedance, amperometry, and so on [26]. Enhanced sensing performance can be achieved by incorporating catalytic reactions of enzymes such as polymerase and recombinase [49]. Such additional steps, such as target gene amplification, dye-labeling, and the addition of enzymes or reagents provide high sensitivity. Although these processes are necessary to additional time and the preparation of the target DNA, they can offer the enhanced reproducibility and sensitivity, and commercial availability.

The second system is based on measuring the impedance change caused by cell lysis [51-54]. Cell viability, one of the bacterial responses to antibiotics, can be used to determine and monitor the change in surface phenomena and material bulk property. One strategy for real-time investigation of the cell viability is to immobilize bacteria or antibiotics on the surface of an electrode. For example, upon antibiotics treatment, surface change depends on the drug susceptibility of bacteria immobilized on the electrode; dead cells with antibiotic-susceptible traits are detached from the electrode, while only the cells resistant to antibiotics live and remain attached. EIS can be an option for detecting changes in the electrode surface because, in low-conducting solutions, the impedance primarily depends on the surface conductivity of the electrode rather than the conductivity of the bulk solution $[55,56]$. As EIS can be used as a label-free sensing system without any redox molecules, miniaturized production with a low cost is possible. A label-free system should be considered for the fabrication of reproducible electrodes and nonspecific adsorption of off-targets in samples, which affects the consistency of the read-out.

The third system is based on the measurement of current response caused by changed membrane properties [57-59]. This system focuses on the change in intrinsic redox prop- 
erties of living bacteria. Ions move through bacterial cell membranes during respiration. Upon exposure to antibiotics, the susceptible cells do not generate electrons because antibiotics can impair the intracellular metabolic pathways, such as the tricarboxylic acid (TCA) cycle and electron transport chain, and thus the current decreases; therefore, cellular current flow is changed. This system can also discriminate between Gram-positive and -negative bacteria owing to their different electron-transfer rates caused by the differences in membrane properties between these two types of bacteria.

The fourth system is based on measuring the change in the redox state of a redox-active molecule affected by bacterial metabolic activity [60-64]. The bacteria are incubated with antibiotics and a redox molecule. Redox molecules such as ferricyanide, resazurin, and methylene blue are added to culture media or embedded with the hydrogel deposited on the electrode. If bacteria are resistant to antibiotics, cells create a reduction environment and reduce the agent, and the change in the redox state of the agent is detected by measuring the decrease in the current. When the susceptible cells are present in the sample, this reduction reaction does not occur, and the current does not change. The concentration of the redox agent should be optimized, and its interference with the antibiotic action or normal cellular functions should be examined.

\section{Current Electrochemical Sensors for the Detection and Monitoring of Antibiotic Resistance in Pathogenic Bacteria}

In this section, we highlight how specific sensors detect antibiotic-resistance levels of bacteria. Representative applications of these sensors, including those described in this paper and others that have been developed and employed for AST are summarized in Table 1.

\subsection{Detection of Antibiotic-Resistant Genes}

The most straightforward method of AST is to explore whether bacteria have antibioticresistant genes or mutants. To this end, multiplex and sensitive evaluation of the abundance and diversity of antibiotic-resistant genes is necessary, but this is a challenging task.

To enhance the sensitivity, isothermal amplification was incorporated with an electrochemical platform and used to detect oxacillin resistance [27] (Figure 1A). A screen-printed gold electrode was functionalized with the target DNA-capturing oligos acting as a primer and treated with isothermal amplification-involved components including dNTPs, another primer, recombinase, polymerase, and horseradish peroxidase (HRP)-labeled dTTP. When the double-stranded target DNA is present, recombinase allows primers to bind to homologous target sequences by unwinding the double-strand without requiring temperature changes or the additional process of preparing ssDNA as the target DNA. Polymerase extends the strand by using the target DNA as a template, where horseradish peroxidases (HRPs) attached to dTTP are incorporated into the newly generated strand. Upon adding $\mathrm{H}_{2} \mathrm{O}_{2}$ and $3,3^{\prime}, 5,5^{\prime}$-tetramethylbenzidine (TMB), HRP replaced TMB with its oxidized state, producing an amperometric readout. Using recombinase-aided isothermal signal amplification and HPR-mediated TMB oxidation, this system could detect $0.69 \mathrm{fM}$ of oxacillin-resistant DNA, corresponding to a $319 \mathrm{CFU} / \mathrm{mL}$ or $10.6 \mathrm{aM}$ target DNA (Table 1). 

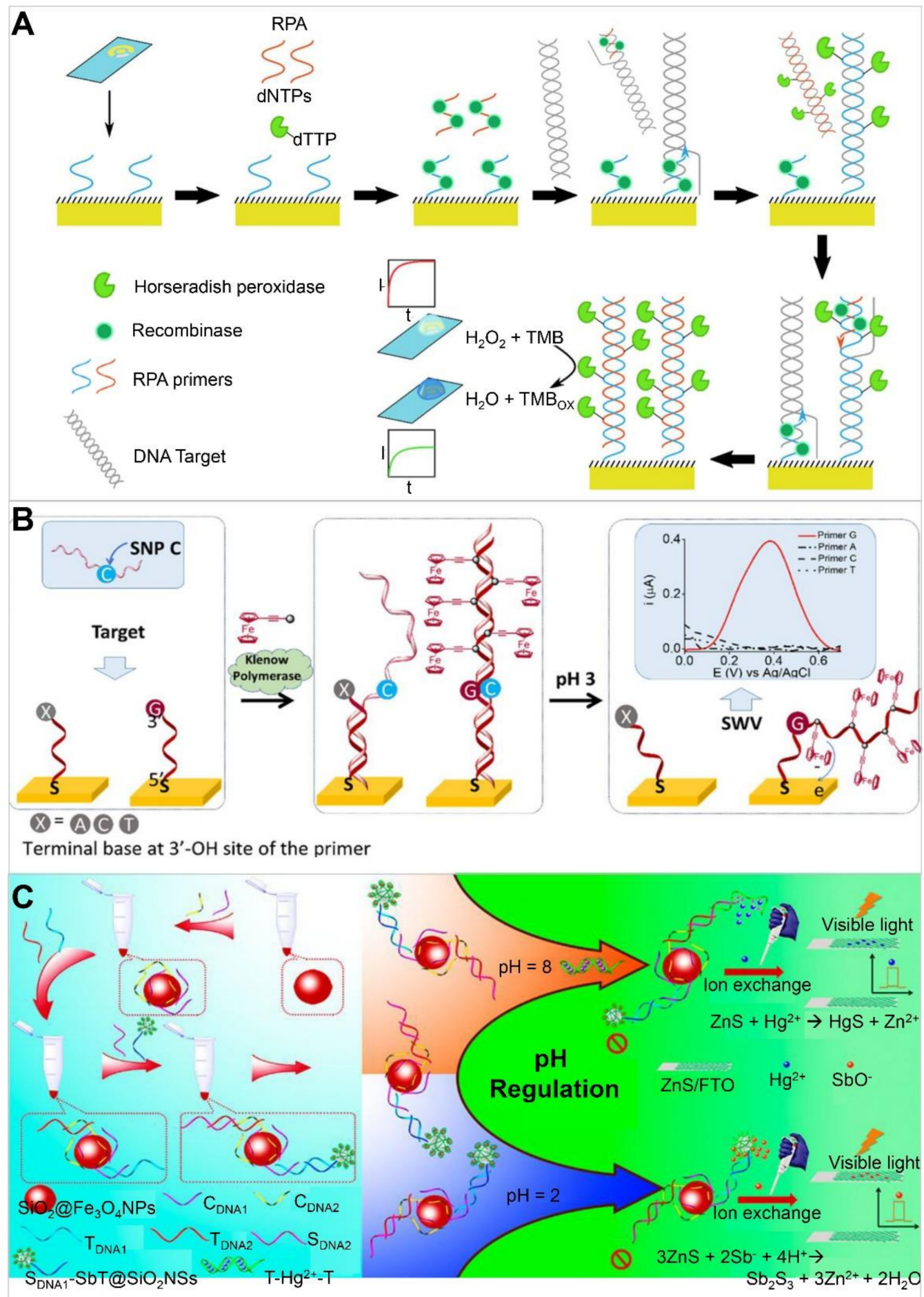

Figure 1. Electrochemical antibiotic susceptibility testing strategy based on the detection of antibioticresistant genes. (A) Isothermal amplification reaction-coupled screen-printed gold electrode for the detection of oxacillin-resistant genes in Escherichia coli. Adapted with permission form [47]. Copyright 2021 American Chemical Society; (B) Solid-phase primer elongation reaction-coupled gold electrode for the detection of rifampicin-resistant genes in Mycobacterium tuberculosis. Adapted with permission form [48]. Copyright 2021 American Chemical Society; (C) pH-controlled metal ion-embedded nanosphere-immobilized on the ZnS modified fluorine tin oxide (FTO) electrode for the detection of penicillin-resistant genes in E. coli. Adapted with permission form [49]. Copyright 2020 American Chemical Society. RPA, recombinase polymerase amplification; TMB, 3,3' ,5,5'-tetramethylbenzidine; SWV, square wave voltammetry. 
Table 1. Examples of electrochemical sensors for antibiotic resistance/susceptibility testing a

\begin{tabular}{|c|c|c|c|c|c|c|c|}
\hline (Working) Electrode & Antibiotics Tested & Target Species & Sensing Approach & Assay Time & Sample & Feature & Reference \\
\hline $\begin{array}{l}\text { Screen printed gold } \\
\text { electrode (SPGE) }\end{array}$ & Oxacillin & Escherichia coli & Chronoamperometry & $60 \mathrm{~min}$ & None & $\begin{array}{c}\text { Use of amperometric change via } \\
\text { HPR-mediated TMB oxidation. Use of } \\
\text { recombinase and polymerase-aided } \\
\text { isothermal amplification. LoD: } \\
319 \mathrm{CFU} / \mathrm{mL} \text {. }\end{array}$ & [47]; Figure 1A \\
\hline Gold electrode & Rifampicin & $\begin{array}{l}\text { Mycobacterium } \\
\text { tuberculosis }\end{array}$ & $\begin{array}{c}\text { Square wave } \\
\text { voltammetry (SWV) }\end{array}$ & $\begin{array}{l}20 \text { min hybridization } \\
\text { with the target, } 5 \mathrm{~min} \\
\text { solid-phase } \\
\text { primer elongation }\end{array}$ & None & $\begin{array}{l}\text { Use of Klenow (exo-) DNA } \\
\text { polymerase-mediated primer } \\
\text { elongation reaction. } \\
\text { Immobilization of thiolated primer on } \\
\text { the surface of gold electrode. } \\
\text { Use of ferrocene-labeled dNTPs. } \\
\text { LoD: } 3 \text { pM ( } 2.7 \times 10^{6} \text { DNA copies) of } \\
\text { target DNAs }\end{array}$ & [48]; Figure 1B \\
\hline $\begin{array}{l}\text { pH-controlled metal } \\
\text { ion-embedded } \\
\text { nanosphere, which was } \\
\text { immobilized on the ZnS } \\
\text { modified fluorine tin } \\
\text { oxide (FTO) substrate }\end{array}$ & Penicillin & E. coli & Photoelectrochemistry & & Plasmid & $\begin{array}{l}\text { Use of change in pH. Linear range: } \\
0.001 \mu \mathrm{M} \text { to } 10 \mu \mathrm{M} \text {. }\end{array}$ & [49]; Figure 1C \\
\hline $\begin{array}{l}\text { Gold electrode with } \\
\text { surface graphene ink }\end{array}$ & Ampicillin & & Impedance & & None & $\begin{array}{l}\text { Linear range: } 6.3-900.0 \mathrm{ng} / \mathrm{mL} \text {. } \\
\text { Detection of DNAs in water. } \\
\text { Immobilization of bacteria on the }\end{array}$ & {$[50]$} \\
\hline $\begin{array}{l}\text { Tantalum silicide } \\
\text { electrode }\end{array}$ & Ampicillin & E. coli & Impedance & $60-120 \mathrm{~min}$ & None & $\begin{array}{l}\text { three-dimensional interdigitated } \\
\text { electrode array impedimetric transducer. } \\
\text { Enables multiple detection or monitoring } \\
\text { using multielectrode by separating via } \\
\text { the insulating barriers. }\end{array}$ & [51]; Figure 2A \\
\hline $\begin{array}{l}\text { Silver interdigitated } \\
\text { carbon working } \\
\text { electrode (WE), counter } \\
\text { electrode (CE), and } \\
\text { reference electrode (RE). } \\
\text { Plastic microchips with } \\
\text { printed electrodes }\end{array}$ & $\begin{array}{l}\text { Ampicillin, } \\
\text { erythromycin, } \\
\text { ciprofloxacin, } \\
\text { methicillin, } \\
\text { daptomycin, gentamicin }\end{array}$ & $\begin{array}{c}\text { E. coli, } \\
\text { Methicillin-resistant } \\
\text { Staphylococcus aureus } \\
\text { (MRSA) }\end{array}$ & Impedance & $<90 \min$ & $\begin{array}{l}\text { Whole blood, } \\
\text { human urine }\end{array}$ & $\begin{array}{l}\text { Immobilization of bacteria on the } \\
\text { electrode by using an antibody. No dye } \\
\text { to interfere with cellular processes. }\end{array}$ & [52]; Figure 2B \\
\hline $\begin{array}{l}\text { SPGE immobilized with } \\
\text { thiolated vancomycin, } \\
\text { which was used as the } \\
\text { binder with } \\
\text { Gram-positive bacteria }\end{array}$ & Vancomycin & S. aureus & Impedance & & None & $\begin{array}{l}\text { Linear range: } 10^{1}-10^{8} \mathrm{CFU} / \mathrm{mL} \text {. } \\
\text { LoD: }<39 \mathrm{CFU} / \mathrm{mL} .\end{array}$ & [53]; Figure 2C \\
\hline $\begin{array}{l}\text { Gold WE, gold CE, } \\
\text { silver RE }\end{array}$ & Amoxicillin, oxacillin & S. aureus, MRSA & $\begin{array}{l}\text { Impedance and } \\
\text { differential pulse } \\
\text { voltammetry (DPV) }\end{array}$ & $<45 \min$ & None & $\begin{array}{l}\text { Drop-coating of three electrodes with a } \\
\text { hydrogel containing agarose, LB growth } \\
\text { media, ferri-ferro cyanide redox } \\
\text { mediator, and antibiotics. Enables a } \\
\text { low-cost and mass production } \\
\text { of electrode. }\end{array}$ & [54]; Figure 2D \\
\hline $\begin{array}{l}\text { L-lysine coated cerium } \\
\text { oxide nanoparticle } \\
\text { coated indium tin oxide } \\
\text { (ITO) }\end{array}$ & $\begin{array}{l}\text { Ciprofloxacin, cefixime, } \\
\text { amoxycillin }\end{array}$ & E. coli & Cyclic voltammetry (CV) & $\begin{array}{l}\text { Measurement time: } \\
15 \mathrm{~min}\end{array}$ & None & $\begin{array}{l}\text { Use of electron-transfer rate due to } \\
\text { different membrane properties of Gram } \\
(+) \text { and }(-) \text { bacteria. }\end{array}$ & [57]; Figure 3 \\
\hline
\end{tabular}


Table 1. Cont.

\begin{tabular}{|c|c|c|c|c|c|c|c|}
\hline (Working) Electrode & Antibiotics Tested & Target Species & Sensing Approach & Assay Time & Sample & Feature & Reference \\
\hline $\begin{array}{l}\text { Miniaturized incubation } \\
\text { chamber containing } \\
\text { working, counter, and } \\
\text { reference electrodes }\end{array}$ & Ampicillin, ciprofloxacin & $\begin{array}{l}\text { E. coli, Klebsiella } \\
\text { pneumoniae }\end{array}$ & DPV & $30 \mathrm{~min}$ & Human urine & $\begin{array}{l}\text { Incubation of living cells with antibiotics } \\
\text { and redox reporter molecules in a } \\
\text { miniaturized chamber. }\end{array}$ & [60] \\
\hline $\begin{array}{l}\text { Gold electrode pattened } \\
\text { on a glass substrate }\end{array}$ & Gentamicin & E. coli, S. aureus & Capacitance & & None & $\begin{array}{c}\text { Use of bacterial-specific } \\
\text { aptamer-functionalized electrode. } \\
\text { Measurement of bacterial growth curves } \\
\text { for } 10 \mathrm{CFU} / \mathrm{mL} \text {. }\end{array}$ & [58] \\
\hline Glassy carbon electrode & $\begin{array}{l}\text { Ofloxacin, penicillin, } \\
\text { cefepime }\end{array}$ & E. coli & DPV & & None & $\begin{array}{l}\text { Immobilization of cells with graphene } \\
\text { dispersion on the electrode surface. }\end{array}$ & [59] \\
\hline $\begin{array}{l}\text { Screen-printed } \\
\text { carbon-graphite } \\
\text { electrode }\end{array}$ & Gentamycin & E. coli & DPV & $90 \mathrm{~min}$ & Artificial urine & $\begin{array}{l}\text { Use of resazurin-containing electrode. } \\
\text { LoD: } 15.6 \mu \mathrm{M}\end{array}$ & [61]; Figure 4A \\
\hline $\begin{array}{l}\text { Platinum WE and } \mathrm{CE}, \\
\mathrm{Ag} / \mathrm{AgCl} \mathrm{RE} \\
\text { Nafion-coated organic } \\
\text { redox-active crystal } \\
\text { layers on planar } \\
\text { pyrolytic graphite sheets } \\
\text { as the sensing platform }\end{array}$ & $\begin{array}{l}\text { Ampicillin, kanamycin, } \\
\text { tetracycline }\end{array}$ & E. coli, K. pneumoniae & $\begin{array}{l}\text { DPV, detection of } \\
\text { resazurin }\end{array}$ & $60 \mathrm{~min}$ & Whole blood, milk & $\begin{array}{c}\text { Reusable biosensor. Electrode type } \\
\text { incompatible with miniaturization. } \\
\text { Use of change in pH via cell proliferation. } \\
\text { Assay time: } 60 \text { min. Stable } \\
\text { (<12\% degradation in } \sim 60 \mathrm{~d}) \text {. Detection } \\
\text { range: } 0.001-10 \mu \mathrm{M}, 0 \mu \mathrm{g} / \mathrm{mL} \text { and } \\
16 \mu \mathrm{mL} \text {. }\end{array}$ & [63]; Figure 4B \\
\hline $\begin{array}{l}\text { Screen-printed carbon } \\
\text { electrode modified with } \\
\text { multi-welled carbon } \\
\text { tube and } \\
\text { gold nanoparticle }\end{array}$ & Ofloxacin, penicillin & Salmonella gallinarum & DPV & $60 \mathrm{~min}$ & Egg & $\begin{array}{l}\text { Single-step modification. Modification } \\
\text { process currently incompatible with bulk } \\
\text { modification. Multi-channel. LoD: } \\
100 \mathrm{CFU} / \mathrm{mL} \text {. }\end{array}$ & [64] \\
\hline
\end{tabular}




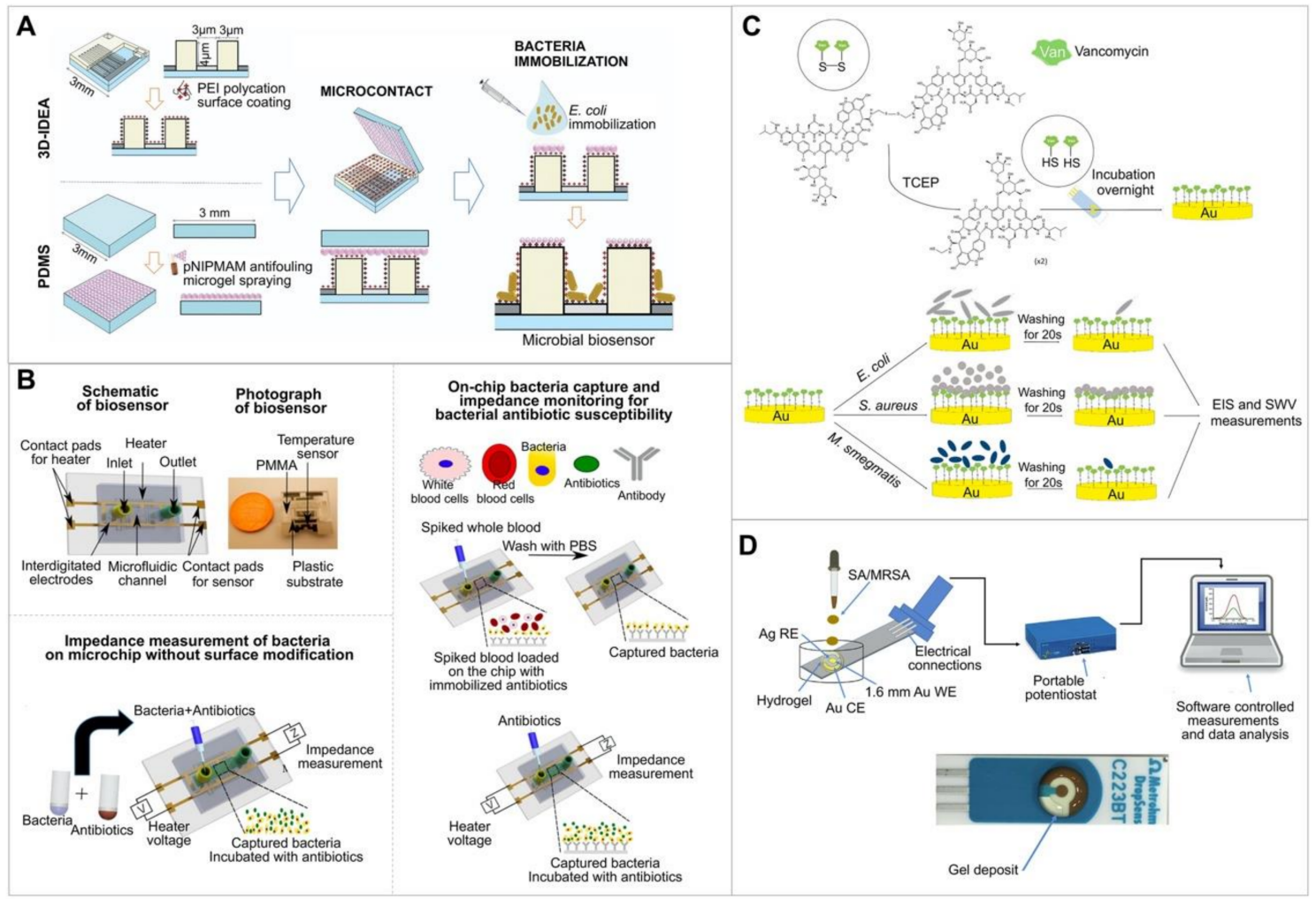

Figure 2. Electrochemical antibiotic susceptibility testing (AST) strategy based on the detection of the change in impedance caused by cell lysis: (A) Bacterial cell-immobilized 3D interdigitated electrode array (3D-IDEA) impedimetric transducer for the AST of Escherichia coli against ampicillin. Adapted with permission form [51]. Copyright 2019 RSC; (B) Bacterial cell-immobilized plastic microchips with printed electrodes for AST of E. coli and methicillin-resistant Staphylococcus aureus (MRSA) against ampicillin erythromycin, ciprofloxacin, methicillin, daptomycin, and gentamicin. Adapted with permission form [52]. Copyright 2017 American Chemical Society; (C) Antibioticimmobilized screen-printed gold electrode (SPGE) for the AST of S. aureus against vancomycin. Adapted with permission form [53]. Copyright 2021 Talanta; (D) Hydrogel-covered three electrodes for the AST of S. aureus (SA) and MRSA against amoxicillin and oxacillin. Adapted with permission form [54]. Copyright 2021 Biosensors and Bioelectronics. PEI, polyethyleneimine; pNIPMAM, poly $\mathrm{N}$-isopropyl methacrylamide; PDMS, polydimethylsiloxane; PMMA, poly methyl methacrylate; TCEP, tris(2-carboxyethyl)phosphine hydrochloride; EIS, electrochemical impedance spectroscopy; SWV, square wave voltammetry; RE, reference electrode; $C E$, counter electrode; $W E$, working electrode.

Solid-tethered primer-extending reaction was also used for the detection of the point mutation associated with rifampicin resistance [48] (Figure 2B). In this system, 5-thiolated primer was attached to the surface of gold electrode via chemisorption. Upon adding Klenow (exo-) DNA polymerase and ferrocene-labeled dNTP, if the sample has target DNA with sequences complementary to primer, polymerase-mediated primer extension reaction occurs and ferrocene-labeled double stranded DNAs are produced, enabling a voltametric detection. When targets with non-fully complimentary sequence to primer exist in sample, the subsequent reactions such as primer elongation and incorporation of ferrocene-labeled dNTP into primer:target duplex do not occur and thus the signal of square wave voltammetry is not observed. Using this system, the point mutation of rifampicin resistance in Mycobacterium tuberculosis strains was unequivocally identified at $3 \mathrm{pM}\left(2.7 \times 10^{6}\right.$ DNA copies) of target DNAs (Table 1$)$. 


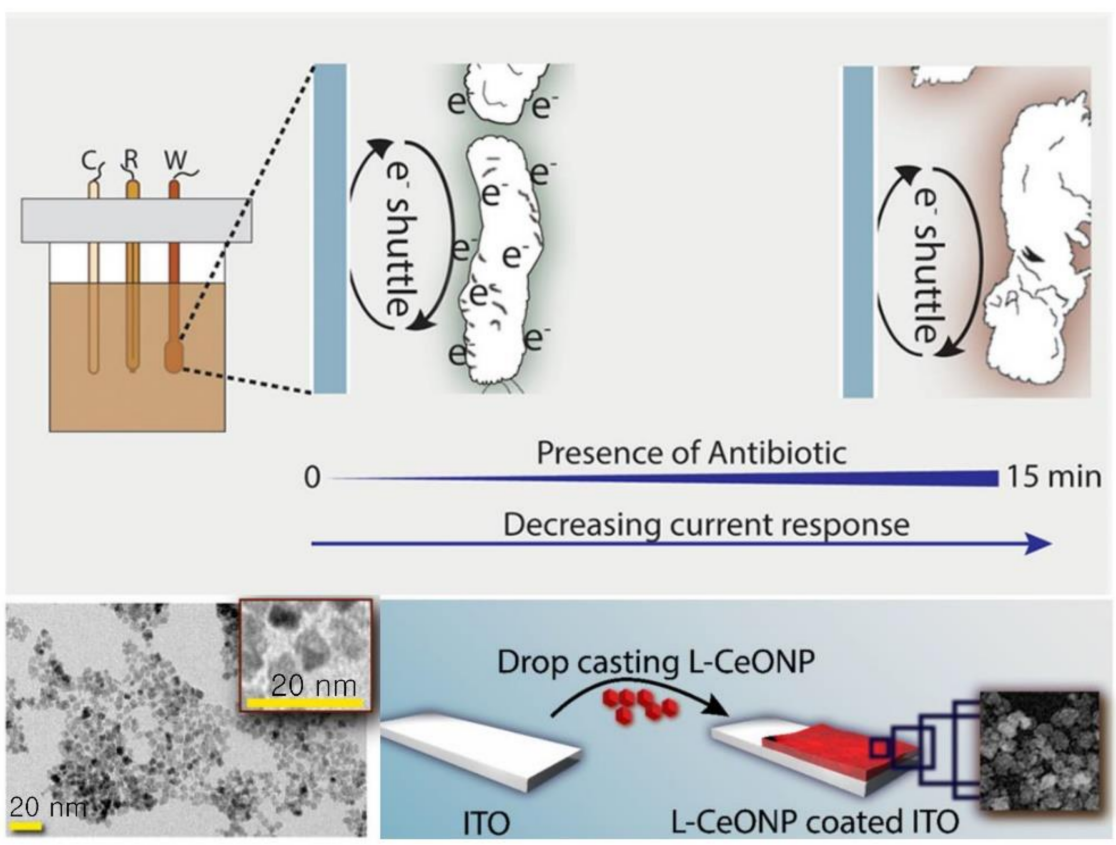

Figure 3. Electrochemical antibiotic susceptibility testing strategy based on monitoring current response caused by changed membrane properties. L-lysine coated cerium oxide nanoparticle (L-CeONP) coated indium tin oxide (ITO) electrode for determining the resistance level of E. coli against ciprofloxacin, cefixime, and amoxycillin. Adapted with permission form [57]. Copyright 2020 American Chemical Society.

One of the recent trends is to use photoelectrochemical approaches due to their high sensitivities, high signal-to-noise ratios resulting from the difference between excitation and detection signals, low cost, and inherent small size. To detect multiple biomolecules in a single assay, the sensing platform of photoelectrochemical sensors is generally constructed by patterning or partitioning electrodes. Specific probes to capture the target molecules are deposited on each small area of electrode. However, it is difficult to cover the overall region of a small area with a light source, which can lower the sensitivity. To overcome this limitation, stimuli-responsive materials were used in the sensing platform [49] (Figure 1C). For example, a pH-controlled platform was used to detect penicillin-resistant genes [49]. This system relies on the $\mathrm{pH}$-controlled release of metal ions embedded in sandwich-type DNAs; the metal ion triggered a structural change in the photoactive material-based substrates, which eventually changed the photocurrent response. In this system, a pH-controlled platform was fabricated with ZnS modified fluorine-doped tin oxide (FTO) substrates. Two different sandwich-type DNAs ( $\mathrm{C}_{\mathrm{DNA} 2}: \mathrm{T}_{\mathrm{DNA} 2}: \mathrm{S}_{\mathrm{DNA} 2}$ and $\left.\mathrm{C}_{\mathrm{DNA} 1}: \mathrm{C}_{\mathrm{DNA} 2}: \mathrm{S}_{\mathrm{DNA} 1}\right)$-functionalized $\mathrm{SiO}_{2} @ \mathrm{Fe}_{3} \mathrm{O}_{4}$ nanoparticles were applied to the substrate. One end of the sandwich DNA, $\mathrm{C}_{\mathrm{DNA} 1}: \mathrm{C}_{\mathrm{DNA} 2}: \mathrm{S}_{\mathrm{DNA} 1}$, was attached with $\mathrm{SbT}_{\mathrm{SSiO}}$ nanospheres, which already binds with trigger DNA $\left(\mathrm{T}_{\mathrm{DNA}}\right)$ harboring $\mathrm{Hg}^{2+}$ via the hairpin thymine $(\mathrm{T})-\mathrm{Hg}^{2+}-\mathrm{T}$ interaction. At $\mathrm{pH} 2$ (acidic), $\mathrm{SbO}^{-}$is released from sandwich DNA and reacts with $\mathrm{ZnS}$, forming the $\mathrm{Sb}_{2} \mathrm{~S}_{3} / \mathrm{ZnS}$ structure via ion exchange and enhancing the photocurrent. At $\mathrm{pH} 8$, the $\mathrm{T}-\mathrm{Hg}^{2+}-\mathrm{T}$ linkage is disrupted because of the preferential binding of trigger DNA to $\mathrm{S}_{\mathrm{DNA} 2}$, and $\mathrm{Hg}^{2+}$ is released, resulting in the formation of the $\mathrm{HgS} / \mathrm{ZnS}$ structure. Using this system, bla-CTX-M-1 ( $\left.\mathrm{T}_{\mathrm{DNA} 1}\right)$ and bla-TEM $\left(\mathrm{T}_{\mathrm{DNA} 2}\right)$ were detected with the linear range from $0.001 \mu \mathrm{M}$ to $10 \mu \mathrm{M}$ at both pHs [49] (Table 1). Even after the development of diverse diagnostic systems, additional considerations remain. For example, the receptors used in multiplex detection sensor are carefully designed to avoid generating false-positive or false-negative results; however, such errors are not always avoidable because of the genetic complexities inherent in microbial species. In an attempt to address these limitations, the use of multiple assay platforms might be needed for the parallel detection and identifica- 
tion of pathogens and antibiotic resistance-associated point mutations within a complex microbial community.

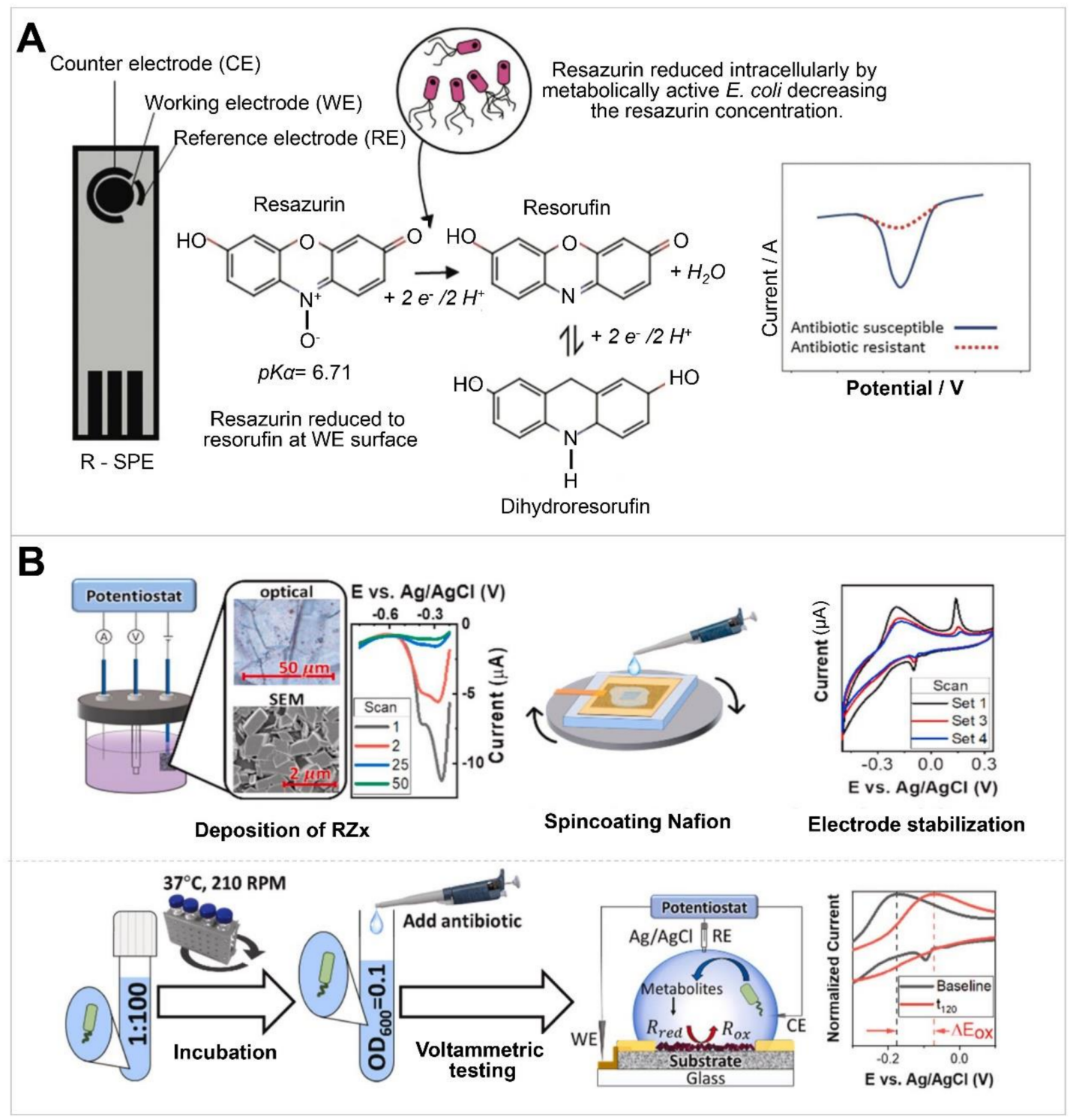

Figure 4. Electrochemical antibiotic susceptibility testing strategy based on the change in the redox state of the redox-active reagent affected by bacterial metabolism: (A) Resazurin-containing screenprinted carbon-graphite electrode for the AST of E. coli against gentamycin. Adapted with permission form [61]. Copyright 2021 RSC.: (B) Nafion-coated resazurin-active crystal layers (RZx) on a planar pyrolytic graphite electrode for the AST of E. coli against ampicillin and kanamycin. Adapted with permission form [63]. Copyright 2021 Biosensors and Bioelectronics.

\subsection{Measurement of the Change in Impedance Caused by Cell Lysis}

Another method for AST measurement is to monitor the change in current flow. Upon exposure to antibiotics, antibiotic-susceptible bacteria can lyse and thus release cytoplasmic components, thereby increasing the current flow and decreasing the impedance. To monitor the response of bacterial cells against antibiotics, sensing platforms typically used electrodes immobilized with either antibiotics or target bacteria.

Bacteria-immobilized electrode-based systems can operate in non-Faradaic mode, which mainly depends on the electrode interfacial capacitance. This mode does not demand the use of any redox species such as ferrocyanide or resazurin in the electrode or electrolyte 
solution to transfer a charge across an interface and thus does not necessitate the use of a reference electrode because of the no need for the DC potential. This label-free system is advantageous for reducing the effort required for assay optimization, such as redox concentration. Another advantage is to enable in situ measurement, at a low cost, using miniaturization and integration with other technologies. As an example, a three-dimensional interdigitated electrode array impedimetric transducer was developed for AST [51] (Figure 2A). In this system, diverse bacteria were spatially immobilized on a $3 \mathrm{D}$ multielectrode fabricated by separating electrode digits with the $\mathrm{SiO}_{2}$ insulating barriers, enabling detection and monitoring in a high-throughput manner. Since the even attachment of bacterial cells on the electrode is one challenge for the reproducibility of cellbased biosensors, poly( $N$-isopropyl methacrylamide) (pNIPMAM) microgels were used as antifouling agents to prevent the adhesion of bacteria on top of barriers. In this system, E. coli cells were attached to the polyethyleneimine (PEI)-coated polydimethylsiloxane (PDMS) substrate of each electrode digit via electrostatic interaction and incubated for $20 \mathrm{~min}$. After treating with antibiotics, the impedance of susceptible bacteria decreased; it might be because the antibiotics could affect the disruption of the cell membrane and the release of intracellular charged components into the surrounding solution during cell lysis (Table 1).

In another study, plastic microchips with printed electrodes were used as the sensing platform [52] (Figure 2B). This platform was immobilized with bacteria using antibodies specific to species. Microchips were fabricated by coating both sides of the plastic substrate; its backside was screen-printed with carbon to control temperature and sensing, and its front side was screen-printed with silver for forming interdigitated electrodes, while attaching double-sided adhesive film and poly(methyl methacrylate) sheets created a closed system to incubate bacteria with antibiotics in this closed system. A whole blood sample was applied to the chip with an immobilized antibody, in which bacteria in the sample to be captured on the chip. Captured bacteria were incubated with antibiotics in a chamber of chips, and impedance was measured. Using this system, ASTs of E. coli and methicillin-resistant Staphylococcus aureus (MRSA) in whole blood and urine samples were tested against diverse antibiotics, including ampicillin, ciprofloxacin, erythromycin, daptomycin, gentamicin, and methicillin by monitoring over $90 \mathrm{~min}$ (Table 1).

In contrast to the bacteria-immobilizing electrode, in the antibiotic-immobilizing electrode, antibiotics act as both a receptor and an effector of current flow because molecules in the bacterial cell wall can specifically bind to antibiotics. For example, a sensing platform was used with a vancomycin-functionalized screen-printed gold electrode (SPGE) [53] (Figure 2C). Thiol-labeled vancomycin was immobilized on the surface of the SPGE, and the presence of bacteria was monitored using electrochemical impedance spectroscopy (EIS). The EIS signal revealed that the Gram-positive vancomycin-susceptible S. aureus bacteria were strongly attached to the sensing platform. EIS signals changed with the linearity range of $10^{8}-10^{1} \mathrm{CFU} / \mathrm{mL}$ of the different concentrations of bacteria. This system showed that $<37 \mathrm{CFU} / \mathrm{mL}$ was the limit of detection (LoD) (Table 1).

Antibiotics can be incorporated into a hydrogel coated on the electrode [54] (Figure 2D). In this system, antibiotics are embedded on the hydrogel that covers three electrodes of a gold screen-printed substrate and contains agarose, the Luria-Bertani (LB) growth medium, and a ferricyonide-ferrocyanide redox mediator. Due to the porous nature of hydrogels, macromolecular polymer gels, the embedded components reach the working electrode surface. Its gel structure enables the addition of diverse redox agents to monitor parameters during cell growth. The use of hydrogel can be applied to the drop-casting strategy as the deposition method to produce a thin gel layer on the electrode surface. Moreover, this strategy has the advantage of being simple and allowing low-cost mass production, compared with the dip-coating method, which requires a large volume of material and hinders the precise modulation of the layer-thickness depending on how long and/or how many times the electrode is immersed in the gel solution. In this system, cells were 
grown on the gel-modified electrodes, and the antibiotic-susceptibility was determined by monitoring the change in impedance $(z)$ as the function of time $(<45 \mathrm{~min})$ (Table 1$)$.

\subsection{Measurement of Current Response Caused by Changes in Membrane Properties}

Antibiotics can affect membrane potentials, resulting in a change in current response. Living bacteria possess intrinsic redox properties that are derived from the permeability and components of the cellular membrane. The membrane permeability affects the intracellular $\mathrm{pH}$ and redox potential. The components consisting of the cell membrane can also affect the redox potential; for example, several redox-sensitive molecules located on the surface of the cell, such as proteins, phospholipids, and saturated and unsaturated fatty acids, could be directly affected by the redox potential of the culture medium. Cofactors of the apoenzyme, such as $\mathrm{Fe}, \mathrm{Zn}$, and $\mathrm{Mg}$, can be oxidized or reduced, altering the susceptibility of these metal ions to the redox potential of the substrate and/or the medium. The change in redox potential by extracellular stimuli or stress can be used to monitor the state of cell growth and identify the bacterial species. For example, the TCA cycle generates an electric potential gradient across the membrane; however, antibiotic exposure can inhibit the metabolic reactions on the TCA cycle and the electron-transport chain, leading to a change in the membrane potential [65]. Some bactericidal antibiotics can activate the cascade reaction causing oxidative damage and cellular death, in which NADH is oxidized via the electrontransport chain of the TCA cycle, the superoxide formation is stimulated, the Fe-S clusters suffer damage, ferrous iron is produced by the Fenton reaction, and finally a hydroxyl radical is formed [65]. Such reactions can alter the peak current and influence the intrinsic redox properties of bacteria. Using this mechanism, a study reported an electrochemical sensor that measures the electrical potential across the membrane within 15 min [57] (Figure 3). This system relies on determining the bacterial concentration using cyclic voltammetry (CV) upon exposure to antibiotics. To perform AST, L-lysine-functionalized cerium oxide nanoparticle coated indium tin oxide (L-CeONP/ITO) was used as a working electrode, which has a high electron-transport rate and is a bacterial-friendly material. ITO as electrode has several advantages such as high electrical conductivity, high optical transparency, easy functionalization by linker molecules, facile adsorption of analytes, simple generation of the working surface area through a single pretreatment process, a low surface resistance, and a high chemical stability and inertness [66-69]. E. coli cells were incubated with phosphate-buffered saline containing $\mathrm{K}_{3} \mathrm{Fe}[\mathrm{CN}]_{6}$ and glucose, and subjected to CV. Unaffected living cells in the presence of antibiotics can consume glucose for respiration and intracellular TCA cycle reaction continues, exhibiting the CV response and a change in current. Antibiotic-susceptible cells suffered damage, resulting in little to no significant change in current. In this system, as the concentration of antibiotics increases, the CV signal decreases, enabling a determination of the inhibitory concentration of drugs that causes $50 \%$ of the maximum inhibition ( $\mathrm{IC}_{50}$ values). The susceptibility of Gram-negative bacteria could be predicted in $<15$ min via CV with minimal reactive oxygen species (ROS) interference.

In another study, bacterial cells were immobilized on the electrode that functionalized with species-specific aptamers as receptor [58]. Amine-modified aptamer was immobilized on glass substrate which was pretreated sequentially (3-aminopropyl)triethoxysilane (APTES), 3,3'-dithiopropionic acid, N-3-dimethylaminopropyl (EDC), and N-hydroxysulfosuccinimide (Sulfo-NHS). Bacterial species specific to aptamer were captured in the electrode and then antibiotics were treated to them. The capture of bacterial cells increases the capacitance, but the cell death induced by antibiotics causes the morphology changes and the detachment from the electrode surface, resulting in a decrease in capacitance. The change of capacitance can monitor antibiotic susceptibility in real time during bacterial cultivation. Using this system, minimum inhibitory concentrations (MICs) of tetracycline-resistant and ampicillin-resistant $E$. coli were detected by observing the decreased capacitance over time (Table 1). 
As another method to immobilize the bacteria on the electrode, E. coli cells were mixed with graphene and then the surface of glassy carbon electrode was modified with graphene-dispersed cells by drop coating method [59]. The cells have their own oxidoreductase system, which has been shown to be involved in electron transfer. Therefore, the bacterial inhibition of these antibiotics was monitored by measuring the reduction currents at different pulse voltammetry (DPV) after treating three different ofloxacin, penicillin, and cefepime. If antibiotics give a negative effect to cell survival, cells are inactive and cannot perform electrochemical catalytic reaction; therefore, the antibiotic-resistant cells maintained the intensity of electrochemical reduction current of DPV over time and the antibiotic-susceptible cells showed a decrease of the reduction currents with time due to a gradual loss of activity of E. coli after the addition of antibiotics [59] (Table 1).

\subsection{Assessment of the Redox Change of a Redox-Active Molecule Resulting from the Bacterial Metabolic Activity}

Some metabolically active bacteria can change the redox state of redox-active molecule. The cellular redox activity can differentiate between live and dead bacteria and access the effectiveness of antibiotics. Thus, resistant profiles of bacteria against antibiotics can be identified by monitoring and analyzing the electrochemical readout of redox-active molecule [61-64]. For example, resazurin, a redox indicator generally used in cell viability assays, can be sequentially reduced to resorufin and dihydroresorufin $[60,70,71]$. Its reduction reaction depends on the cell's growth phase and concentration. The reduction of resazurin decreases the current peak due to the reduced environment of the viable cells. Using this property, one study reported an AST sensor that uses resazurin as redox reporter molecules [60]. In this system, bacteria are incubated with antibiotics and resazurin in a miniaturized chamber containing a working counter and reference electrode. If bacteria were resistant to antibiotics, they lived and caused an electrochemical reduction of resazurin, reducing the level of resazurin. However, antibiotic-susceptible bacteria did not reduce resazurin. This system characterized the antibiotic-resistant profiles of bacteria through real-time cultivation (30-min period) without a pre-cultivation step (Table 1). In the same strategy, resazurin was mixed with carbon-graphitic ink and the mixture was screen-printed on the working electrode [61] (Figure 4A; Table 1). By measuring the DPV from this electrode, the level of the resistance of $E$. coli to gentamycin could be determined within 90 min. Using the electrode with a thin platinum film on the glass, resazurin was also used as redox-active molecules and could assess the resistance of Klebsiella pneumoniae and E. coli to three different antibiotics-ampicillin, kanamycin, and tetracycline-at $10^{4} \mathrm{CFU} / \mathrm{mL}$ cells within $4 \mathrm{~h}$ [62] (Table 1).

A recent study also used the $\mathrm{pH}$-responsive substrate, which is fabricated with organic redox-active crystal layers on a graphene-based electrode [63] (Figure 4B). The pH change due to cell proliferation was accelerated when a $\mathrm{pH}$-responsive substrate was covered with Nafion, a cation-exchange membrane. In this system, the redox reagent, resazurin, is electrodeposited on planar pyrolytic graphite sheets (PGS), and no additional step of a redox reagent to the culture medium is required. This reagent-free system is advantageous to detect antibiotic-resistant cells in culture media because the redox reagent can interfere with the antibiotic action or normal cellular functions, resulting in inaccurate detection of MIC values. The substrate is designed to interact less with other cations and to be resistant to temperature changes. This system detected $\mathrm{pH}$ changes caused by cell growth and the sensitivity of the device was enhanced by spin-coating Nafion on the electrode, which acts as a cation-exchange membrane and increases the peak height at the oxidation peak. Graphitic materials can also be used to sensitively monitor the change in redox because their morphology enables crystal formation with a high density and surface coverage. Using this system, the MICs of E. coli K-12 treated with ampicillin and kanamycin were determined in $60 \mathrm{~min}$ (Table 1).

The antibiotic resistance was detected at single cell level by using electrochemical collision technique [39]. Electrochemical collision technique relies on collision events 
detected from the change in diffusion current at the ultramicroelectrode (UME). This method can be divided two categories according to which of electrochemical processes is used for the detection: direct and mediated collision electrochemistry. In contrast with the mediated method using surface blocking collisions, the direct collision electrochemistry is based on measuring changes in the current from oxidation or reduction of the particles. In this method, the redox change of particles, redox-active molecules, arises from electron transfer between particles and the electrode. The reduced or oxidized particles can be regenerated by the intrinsic redox activity of living bacterial cell. Using this strategy, the cell viability upon antibiotics exposure was investigated [39]. The addition of E. coli cells on the electrode induced a steady increase of the current because ferricyanide reduction by cells and ferrocyanide oxidation at the UME continuously occur. After treating cobalt ions as antibacterial agents, the current dropped because of cell death. The drug resistance could be monitored and detected via the current-time recoding. In another study, bacteria and redox-active molecule were mixed and applied to UME [40]. As surface charge of $E$. coli is negative and thionine used as redox-active molecule has positive charge, thionine can be absorbed on the bacterial surface by electrostatic interaction. Bacterial metabolic activity can lead the reduction of thionine. The reduced thionine can be re-oxidized via its collision on the UME. The viability of bacterial cell could be evaluated by measuring the change of current.

\section{Conclusions and Outlook}

Pathogen detection is becoming increasingly important in clinical research, forensics, biodefense, food safety, and animal health care. One major challenge confronting the field of pathogen diagnostics is the fast and accurate characterization of antibiotic resistance/susceptibility of infecting species or strains in various settings to prescribe appropriate antibiotics to patients and regions at an early stage. In this regard, electrochemical sensors have garnered increasing attention due to their powerful potential for rapid, sensitive, and real-time monitoring, low-cost production, and ease of minimization and integration with other techniques. In this review, we summarized recent electrochemical AST sensors based on diverse sensing strategies. As already discussed, they have been developed via diverse sensing strategies based on the electrochemical responses derived from the interactions of bacterial cells with antibiotics.

Despite significant advances in electrochemical sensors, there is currently an everincreasing demand for AST in clinical and environment settings, which highlights the need for further biosensing device development. For example, by distinguishing polymicrobial samples, the technique should be able to detect and identify bacterial species from complex samples. Similarly, the technique should be capable of detecting the level of drug resistance of specific bacterial species from complex bacteria that are not cultured isolates. A redox reagent-free or biocompatible reagent-enabled strategy is another challenging task. Electrochemical sensors can detect molecules by measuring the change of the redox state of the redox reagent which is caused by the change of bacterial metabolic activity upon antibiotics exposure. The redox reagents, such as ferricyanide and resazurin, are generally added to culture media $[29,57,60,62,72]$; however, these reagents can interfere with the antibiotic action or physiological cellular functions. This interference causes inaccurate assessment of antibiotic resistance. Additionally, multiplex detection should be addressed. The 3D-printing technology can be used to fabricate multiple biorecognition elements on a single electrode with a fine-tuned and reproducible platform [41,42,73]. In addition, the technique should cover a broad dynamic range for the quantification of drug resistance.

With such challenges and efforts to overcome limitations, we believe that electrochemical sensors will continue to evolve and facilitate AST devices with high sensitivity, specificity, low cost, high-throughput detection, biocompatibility, and simple and fast response, thereby increasing their practical application in clinical and environmental settings, even in resource-limited regions. 
Author Contributions: Conceptualization: D.K. and S.Y. Writing: D.K. and S.Y. Supervision: S.Y. Funding acquisition: S.Y. All authors have read and agreed to the published version of the manuscript.

Funding: This work was supported by an NRF grant funded by the Ministry of Science and ICT (grant number NRF-2019R1A2C1088504).

Institutional Review Board Statement: Not applicable.

Informed Consent Statement: Not applicable.

Data Availability Statement: No new data were generated in this study, and thus data-sharing does not apply to this article.

Conflicts of Interest: The authors declare no conflict of interest.

\section{References}

1. Centers for Disease Control and Prevention. Antibiotic Resistance Threats in the United States 2019; Centers for Disease Control and Prevention (CDC), U.S. Department of Health and Human Services: Atlanta, GA, USA, 2019.

2. Cassini, A.; Högberg, L.D.; Plachouras, D.; Quattrocchi, A.; Hoxha, A.; Simonsen, G.S.; Colomb-Cotinat, M.; Kretzschmar, M.E.; Devleesschauwer, B.; Cecchini, M.; et al. Burden of AMR Collaborative Group. Attributable deaths and disability-adjusted lifeyears caused by infections with antibiotic-resistant bacteria in the EU and the European Economic Area in 2015: A population-level modelling analysis. Lancet Infect. Dis. 2019, 19, 56-66. [CrossRef]

3. Brogan, D.M.; Mossialos, E. A critical analysis of the review on antimicrobial resistance report and the infectious disease financing facility. Glob. Health 2016, 12, 8. [CrossRef] [PubMed]

4. Leonard, H.; Colodner, R.; Halachmi, S.; Segal, E. Recent advances in the race to design a rapid diagnostic test for antimicrobial resistance. ACS Sens. 2018, 3, 2202-2217. [CrossRef] [PubMed]

5. Wang, R.N.; Zhang, Y.; Cao, Z.H.; Wang, X.Y.; Ma, B.; Wu, W.B.; Hu, N.; Huo, Z.Y.; Yuan, Q.B. Occurrence of super antibiotic resistance genes in the downstream of the Yangtze River in China: Prevalence and antibiotic resistance profiles. Sci. Total Environ. 2019, 651 Pt 2, 1946-1957. [CrossRef]

6. Gilligan, P.H. Identification of pathogens by classical clinical tests. In The Prokaryotes; Rosenberg, E., DeLong, E.F., Lory, S., Stackebrandt, E., Thompson, F., Eds.; Springer: Berlin/Heidelberg, Germany, 2013.

7. Davenport, M.; Mach, K.E.; Shortliffe, L.M.D.; Banaei, N.; Wang, T.H.; Liao, J.C. New and developing diagnostic technologies for urinary tract infections. Nat. Rev. Urol. 2017, 14, 296-310. [CrossRef]

8. Narayana Iyengar, S.; Dietvorst, J.; Ferrer-Vilanova, A.; Guirado, G.; Muñoz-Berbel, X.; Russom, A. Toward rapid detection of viable bacteria in whole blood for early sepsis diagnostics and susceptibility testing. ACS Sens. 2021, 6, 3357-3366. [CrossRef]

9. Schuetz, A.N. Antimicrobial resistance and susceptibility testing of anaerobic bacteria. Clin. Infect. Dis. 2014, 59, 698-705. [CrossRef]

10. Vasala, A.; Hytönen, V.P.; Laitinen, O.H. Modern tools for rapid diagnostics of antimicrobial resistance. Front. Cell. Infect. Microbiol. 2020, 10, 308. [CrossRef]

11. Chen, C.; Hong, W. Recent development of rapid antimicrobial susceptibility testing methods through metabolic profiling of bacteria. Antibiotics 2021, 10, 311. [CrossRef]

12. Khan, Z.A.; Siddiqui, M.F.; Park, S. Current and emerging methods of antibiotic susceptibility testing. Diagnostics 2019, 9, 49. [CrossRef]

13. Majdinasab, M.; Mitsubayashi, K.; Marty, J.L. Optical and electrochemical sensors and biosensors for the detection of quinolones. Trends Biotechnol. 2019, 37, 898-915. [CrossRef]

14. Qin, N.; Zhao, P.; Ho, E.A.; Xin, G.; Ren, C.L. Microfluidic technology for antibacterial resistance study and antibiotic susceptibility testing: Review and perspective. ACS Sens. 2021, 6, 3-21. [CrossRef]

15. Yoo, S.M.; Lee, S.Y. Optical biosensors for the detection of pathogenic microorganisms. Trends Biotechnol. 2016, 34, 7-25. [CrossRef]

16. Yin, X.; Hou, T.; Huang, B.; Yang, L.; Li, F. Aptamer recognition-trigged label-free homogeneous electrochemical strategy for an ultrasensitive cancer-derived exosome assay. Chem. Commun. 2019, 55, 13705-13708. [CrossRef]

17. Gai, P.; Gu, C.; Hou, T.; Li, F. Ultrasensitive self-powered aptasensor based on enzyme biofuel cell and DNA bioconjugate, A facile and powerful tool for antibiotic residue detection. Anal. Chem. 2017, 89, 2163-2169. [CrossRef]

18. Chang, J.; Lv, W.; Li, Q.; Li, H.; Li, F. One-step synthesis of methylene blue-encapsulated zeolitic imidazolate framework for dual-signal fluorescent and homogeneous electrochemical biosensing. Anal. Chem. 2020, 92, 8959-8964. [CrossRef]

19. Kaya, H.O.; Cetin, A.E.; Azimzadeh, M.; Topkaya, S.N. Pathogen detection with electrochemical biosensors: Advantages, challenges and future perspectives. J. Electroanal. Chem. 2021, 882, 114989. [CrossRef]

20. Huang, L.; Tian, S.; Zhao, W.; Liu, K.; Guo, J. Electrochemical vitamin sensors: A critical review. Talanta 2021, $222,121645$. [CrossRef]

21. Zhang, Y.; Lei, Y.; Lu, H.; Shi, L.; Wang, P.; Ali, Z.; Li, J. Electrochemical detection of bisphenols in food: A review. Food Chem. 2021, 346, 128895. [CrossRef]

22. Cesewski, E.; Johnson, B.N. Electrochemical biosensors for pathogen detection. Biosens. Bioelectron. 2020, 159, 112214. [CrossRef] 
23. Sheikhzadeh, E.; Beni, V.; Zourob, M. Nanomaterial application in bio/sensors for the detection of infectious diseases. Talanta 2021, 230, 122026. [CrossRef]

24. Garkani Nejad, F.; Tajik, S.; Beitollahi, H.; Sheikhshoaie, I. Magnetic nanomaterials based electrochemical (bio)sensors for food analysis. Talanta 2021, 228, 122075. [CrossRef]

25. Muniandy, S.; Teh, S.J.; Thong, K.L.; Thiha, A.; Dinshaw, I.J.; Lai, C.W.; Ibrahim, F.; Leo, B.F. Carbon Nanomaterial-based electrochemical biosensors for foodborne bacterial detection. Crit. Rev. Anal. Chem. 2019, 49, 510-533. [CrossRef]

26. Trotter, M.; Borst, N.; Thewes, R.; von Stetten, F. Review, Electrochemical DNA sensing-Principles, commercial systems, and applications. Biosens. Bioelectron. 2020, 154, 112069. [CrossRef]

27. Lee, V.B.C.; Mohd-Naim, N.F.; Tamiya, E.; Ahmed, M.U. Trends in paper-based electrochemical biosensors, from design to application. Anal. Sci. 2018, 34, 7-18. [CrossRef]

28. Karbelkar, A.A.; Furst, A.L. Electrochemical diagnostics for bacterial infectious diseases. ACS Infect. Dis. 2020, 6, 1567-1571. [CrossRef]

29. Kang, M.; Jo, Y.; Mun, C.W.; Yeom, J.; Park, J.S.; Jung, H.S.; Kim, D.-H.; Park, S.-G.; Yoo, S.M. Nanoconfined 3D redox capacitorbased electrochemical sensor for ultrasensitive monitoring of metabolites in bacterial communication. Sens. Actuators B-Chem. 2021, 345, 130427. [CrossRef]

30. Zhang, R.; Belwal, T.; Li, L.; Lin, X.; Xu, Y.; Luo, Z. Nanomaterial-based biosensors for sensing key foodborne pathogens, Advances from recent decades. Compr. Rev. Food Sci. Food Saf. 2020, 19, 1465-1487. [CrossRef] [PubMed]

31. Wongkaew, N.; Simsek, M.; Griesche, C.; Baeumner, A.J. Functional nanomaterials and nanostructures enhancing electrochemical biosensors and lab-on-a-chip performances, recent progress, applications, and future perspective. Chem. Rev. 2019, 119, 120-194. [CrossRef] [PubMed]

32. Zhu, C.; Yang, G.; Li, H.; Du, D.; Lin, Y. Electrochemical sensors and biosensors based on nanomaterials and nanostructures. Anal. Chem. 2015, 87, 230-249. [CrossRef] [PubMed]

33. Amali, R.K.A.; Lim, H.N.; Ibrahim, I.; Huang, N.M.; Zainal, Z.; Ahmad, S.A.A. Significance of nanomaterials in electrochemical sensors for nitrate detection, A review. Trends Environ. Anal. Chem. 2021, 31, e00135. [CrossRef]

34. Kang, M.; Mun, C.; Jung, H.S.; Ansah, I.B.; Kim, E.; Yang, H.; Payne, G.F.; Kim, D.H.; Park, S.G. Tethered molecular redox capacitors for nanoconfinement-assisted electrochemical signal amplification. Nanoscale 2020, 12, 3668-3676. [CrossRef]

35. Lemay, S.G.; Moazzenzade, T. Single-entity electrochemistry for digital biosensing at ultralow concentrations. Anal. Chem. 2021, 93, 9023-9031. [CrossRef]

36. Nguyen, T.H.T.; Lee, J.; Kim, H.Y.; Nam, K.M.; Kim, B.K. Current research on single-entity electrochemistry for soft nanoparticle detection, Introduction to detection methods and applications. Biosens. Bioelectron. 2020, 151, 111999. [CrossRef]

37. Zhang, J.-H.; Zhou, Y.-G. Nano-impact electrochemistry, Analysis of single bioentities. TrAC-Trends Anal. Chem. 2020, 123, 115768. [CrossRef]

38. Couto, R.A.S.; Chen, L.; Kuss, S.; Compton, R.G. Detection of Escherichia coli bacteria by impact electrochemistry. Analyst 2018, 143, 4840-4843. [CrossRef]

39. Gao, G.; Wang, D.; Brocenschi, R.; Zhi, J.; Mirkin, M.V. Toward the detection and identification of single bacteria by electrochemical collision technique. Anal. Chem. 2018, 90, 12123-12130. [CrossRef]

40. Chen, Y.; Wang, D.; Liu, Y.; Gao, G.; Zhi, J. Redox activity of single bacteria revealed by electrochemical collision technique. Biosens. Bioelectron. 2021, 176, 112914. [CrossRef]

41. Cardoso, R.M.; Kalinke, C.; Rocha, R.G.; Dos Santos, P.L.; Rocha, D.P.; Oliveira, P.R.; Janegitz, B.C.; Bonacin, J.A.; Richter, E.M.; Munoz, R. Additive-manufactured (3D-printed) electrochemical sensors: A critical review. Anal. Chim. Acta. 2020, 1118, 73-91. [CrossRef]

42. Ambaye, A.D.; Kefeni, K.K.; Mishra, S.B.; Nxumalo, E.N.; Ntsendwana, B. Recent developments in nanotechnology-based printing electrode systems for electrochemical sensors. Talanta 2021, 225, 121951. [CrossRef]

43. Grieshaber, D.; MacKenzie, R.; Vörös, J.; Reimhult, E. Electrochemical biosensors-Sensor principles and architectures. Sensors 2008, 8, 1400-1458. [CrossRef]

44. Ferapontova, E.E. Hybridization biosensors relying on electrical properties of nucleic acids. Electroanalysis 2017, 29 , 6-13. [CrossRef]

45. Ferapontova, E.E. DNA Electrochemistry and Electrochemical sensors for nucleic acids. Annu. Rev. Anal. Chem. 2018, 11, 197-218. [CrossRef]

46. Paleček, E.; Bartošík, M. Electrochemistry of nucleic acids. Chem. Rev. 2012, 112, 3427-3481. [CrossRef]

47. Butterworth, A.; Pratibha, P.; Marx, A.; Corrigan, D.K. Electrochemical detection of oxacillin resistance using direct-labeling solid-phase isothermal amplification. ACS Sens. 2021, 6, 3773-3780. [CrossRef]

48. Ortiz, M.; Jauset-Rubio, M.; Skouridou, V.; Machado, D.; Viveiros, M.; Clark, T.G.; Simonova, A.; Kodr, D.; Hocek, M.; O'Sullivan, C.K. Electrochemical detection of single-nucleotide polymorphism associated with rifampicin resistance in $M y-$ cobacterium tuberculosis using solid-phase primer elongation with ferrocene-linked redox-labeled nucleotides. ACS Sens. 2021, 6, 4398-4407. [CrossRef]

49. Li, X.; Lu, J.; Feng, L.; Zhang, L.; Gong, J. Smart pH-regulated switchable nanoprobes for photoelectrochemical multiplex detection of antibiotic resistance genes. Anal. Chem. 2020, 92, 11476-11483. [CrossRef] 
50. Wan, C.; Qu, A.; Li, M.; Tang, R.; Fu, L.; Liu, X.; Wang, P.; Wu, C. Electrochemical sensor for directional recognition and measurement of antibiotic resistance genes in water. Anal. Chem. 2022, 94, 732-739. [CrossRef]

51. Brosel-Oliu, S.; Mergel, O.; Uria, N.; Abramova, N.; van Rijn, P.; Bratov, A. 3D impedimetric sensors as a tool for monitoring bacterial response to antibiotics. Lab Chip 2019, 19, 1436-1447. [CrossRef]

52. Safavieh, M.; Pandya, H.J.; Venkataraman, M.; Thirumalaraju, P.; Kanakasabapathy, M.K.; Singh, A.; Prabhakar, D.; Chug, M.K.; Shafiee, H. Rapid real-time antimicrobial susceptibility testing with electrical sensing on plastic microchips with printed electrodes. ACS Appl. Mater. Interfaces 2017, 9, 12832-12840. [CrossRef]

53. Dizaji, A.N.; Ali, Z.; Ghorbanpoor, H.; Ozturk, Y.; Akcakoca, I.; Avci, H.; Dogan Guzel, F. Electrochemical-based "antibiotsensor" for the whole-cell detection of the vancomycin-susceptible bacteria. Talanta 2021, 234, 122695. [CrossRef] [PubMed]

54. Hannah, S.; Addington, E.; Alcorn, D.; Shu, W.; Hoskisson, P.A.; Corrigan, D.K. Rapid antibiotic susceptibility testing using low-cost, commercially available screen-printed electrodes. Biosens. Bioelectron. 2019, 145, 111696. [CrossRef] [PubMed]

55. Guimerà, A.; Gabriel, G.; Prats-Alfonso, E.; Abramova, N.; Bratov, A.; Villa, R. Effect of surface conductivity on the sensitivity of interdigitated impedimetric sensors and their design considerations. Sens. Actuators B-Chem. 2015, 207, 1010-1018. [CrossRef]

56. Bratov, A.; Abramova, N. Response of a microcapillary impedimetric transducer to changes in surface conductance at liquid/solid interface. J. Colloid Interface Sci. 2013, 403, 151-156. [CrossRef] [PubMed]

57. Rao, R.P.; Sharma, S.; Mehrotra, T.; Das, R.; Kumar, R.; Singh, R.; Roy, I.; Basu, T. Rapid electrochemical monitoring of bacterial respiration for Gram-positive and Gram-negative microbes: Potential application in antimicrobial susceptibility testing. Anal. Chem. 2020, 92, 4266-4274. [CrossRef]

58. Jo, N.; Kim, B.; Lee, S.M.; Oh, J.; Park, I.H.; Lim, K.J.; Shin, J.S.; Yoo, K.H. Aptamer-functionalized capacitance sensors for real-time monitoring of bacterial growth and antibiotic susceptibility. Biosens. Bioelectron. 2018, 102, 164-170. [CrossRef]

59. Li, C.; Sun, F. Graphene-assisted sensor for rapid detection of antibiotic resistance in Escherichia coli. Front. Chem. 2021, 9, 696906. [CrossRef]

60. Besant, J.D.; Sargent, E.H.; Kelley, S.O. Rapid electrochemical phenotypic profiling of antibiotic-resistant bacteria. Lab Chip 2015, 15, 2799-2807. [CrossRef]

61. Crane, B.; Hughes, J.; Neale, S.J.R.; Rashid, M.; Linton, P.E.; Banks, C.E.; Shaw, K. Rapid antibiotic susceptibility testing using resazurin bulk modified screen-printed electrochemical sensing platforms. Analyst 2021, 146, 5574-5583. [CrossRef]

62. Mishra, P.; Singh, D.; Mishra, K.P.; Kaur, G.; Dhull, N.; Tomar, M.; Gupta, V.; Kumar, B.; Ganju, L. Rapid antibiotic susceptibility testing by resazurin using thin film platinum as a bio-electrode. J. Microbiol. Methods 2019, 162, 69-76. [CrossRef]

63. Bolotsky, A.; Muralidharan, R.; Butler, D.; Root, K.; Murray, W.; Liu, Z.; Ebrahimi, A. Organic redox-active crystalline layers for reagent-free electrochemical antibiotic susceptibility testing (ORACLE-AST). Biosens. Bioelectron. 2021, 172, 112615. [CrossRef]

64. Ren, Y.; Ji, J.; Sun, J.; Pi, F.; Zhang, Y.; Sun, X. Rapid detection of antibiotic resistance in Salmonella with screen printed carbon electrodes. J. Solid State Electrochem. 2020, 24, 1539-1549. [CrossRef]

65. Kohanski, M.A.; Dwyer, D.J.; Hayete, B.; Lawrence, C.A.; Collins, J.J. A common mechanism of cellular death induced by bactericidal antibiotics. Cell 2007, 130, 797-810. [CrossRef]

66. Jung, J.; Lee, J.; Shin, S.; Kim, Y.T. Development of a telemetric, miniaturized electrochemical amperometric analyzer. Sensors 2017, 17, 2416. [CrossRef]

67. Chae, Y.K.; Kim, S.H.; Ellinger, J.E.; Markley, J.L. Dosage effects of salt and pH stresses on Saccharomyces cerevisiae as monitored via metabolites by using two dimensional NMR Spectroscopy. Bull. Korean Chem. Soc. 2013, 34, 3602-3608. [CrossRef]

68. Ranganathan, S.; Kuo, T.C.; McCreery, R.L. Facile preparation of active glassy carbon electrodes with activated carbon and organic solvents. Anal. Chem. 1999, 71, 3574-3580. [CrossRef]

69. Woods, L.A.; Powell, P.R.; Paxon, T.L.; Ewing, A.G. Analysis of mammalian cell cytoplasm with electrophoresis in nanometer inner diameter capillaries. Electroanalysis 2005, 17, 1192-1197. [CrossRef]

70. Chen, J.L.; Steele, T.W.J.; Stuckey, D.C. Metabolic reduction of resazurin; location within the cell for cytotoxicity assays. Biotechnol. Bioeng. 2018, 115, 351-358. [CrossRef]

71. Rampersad, S.N. Multiple applications of Alamar blue as an indicator of metabolic function and cellular health in cell viability bioassays. Sensors 2012, 12, 12347-12360. [CrossRef]

72. Chotinantakul, K.; Suginta, W.; Schulte, A. Advanced amperometric respiration assay for antimicrobial susceptibility testing Anal. Chem. 2014, 86, 10315-10322. [CrossRef]

73. Katseli, V.; Economou, A.; Kokkinos, C. Single-step fabrication of an integrated 3D-printed device for electrochemical sensing applications. Electrochem. Commun. 2019, 103, 100-103. [CrossRef] 